ПOЛИTИЧECRИE HAYRИ

КУЛЬТУРНО ГУМАНИТАРНЫЕ АСПЕКТЫ УЗБЕКСКО - АФГАНСКИХ ОТНОШЕНИЙ

DOI: $10.31618 /$ ESU.2413-9335.2019.5.66.317

Жураев Сайфиддин Ахматович

доктор политологических наук, профессор

Ташкентского государственного института востоковедения.

\title{
CULTURAL AND HUMANITARIAN ASPECTS OF UZBEK - AFGHAN RELATIONS
}

\author{
Zhuraev Sayfiddin Akhmatovich \\ Doctor of Political Science, Professor \\ of the Tashkent State Institute of Oriental Studies.
}

\section{АННОТАЦИЯ}

В данной статье рассматривается культурно гуманитарный фактор как система образующий элемент двухсторонних отношений. Показывается некоторые тенденции культурно гуманитарном сотрудничестве между Узбекистаном и Афганистаном. Особое внимание уделяется конференционную дипломатию как фактор развитии культурно гуманитарного сотрудничества.

\section{ANNOTATION}

This article discusses the cultural and humanitarian factor as a system forming an element of bilateral relations. Some tendencies of cultural and humanitarian cooperation between Uzbekistan and Afghanistan are shown. Particular attention is paid to conference diplomacy as a factor in the development of cultural and humanitarian cooperation.

Ключевые слова. Культурные ценности. Народная дипломатия. Общества дружбы «Узбекистан Афганистан». Термезский образовательный центр. Конференционная дипломатия.

Keywords. Cultural values. People's diplomacy. Friendship Society "Uzbekistan - Afghanistan". Termez educational center. Conference diplomacy.

\section{Введение}

На сегодняшний день во взаимоотношениях между Узбекистаном и Афганистана появился усиливающие новые тенденции. За последнее три года состоялись семи встречи между Президентом Ш.Мирзиёева и А.Гани, которого раньше не было, поэтому эти встречи и принимаемые решение носит исторический характер. Заметно активизировался делегационный обмен между экономическими ведомствами двух стран; подписан и постепенно реализуются ряд двусторонних документов, в том числе «Дорожная карта» по дальнейшему развитию полномасштабного сотрудничества между двумя государствами. Начался работа по торгово экономическом сотрудничестве, пунктах пропуска через государственную границу, оказание правовой помощи по гражданским, семейным делам, сотрудничестве в области транзита грузов, взаимном содействии в таможенных делах, сотрудничестве в сферах сельского хозяйства, энергетики, здравоохранения, высшего образования.

Сегодня важным стратегическим задачей стал пополнений этих действие реальным участием представителей науки, образовании, культуры ${ }^{1}$ этом направлении Ташкент предпринимает

1 Данная статья поготовлена на основе представленных докладов автора на международную конференцию «Афганистан на пороге XX и XXI веков: исторические, социально-экономические и политические аспекты, вопросы взаимного сотрудничества со странами Центральной Азии.» 21- 22 июнья 2019 года в активные меры по расширению культурногуманитарного сотрудничества. В частности начата работа совместной реставрации, ремонте и благоустройстве являющихся символом общего культурно-духовного наследия мест упокоения Абу Райхана Беруни, Алишера Навои, Захириддина Мухаммада Бабура и других великих ученых и мыслителей; Узбекистан начал обучать в своих высших учебных заведениях специалистов для Афганистана.

Значение культурно гуманитарного фактора в международных отношениях

Актуальность усиления культурно гуманитарных факторов двухсторонних и многосторонних отношений между государствами обусловлена Во первых, возрастанием роли культурно гуманитарные составляющие современных международных отношениях также складывающиеся современная геополитические ситуация в мире и в Азиатском регионе, вызванные последствием рядом глобальных процессов, которые заставили внести коррективы во внешнеполитический действиях современных. Новые развивающие страны вынуждены учитывать, что в современных условиях ведущим игрокам мировой политике стала присуши

г.Ташкенте. Которую организовал Ташкентский государственный институт Востоковедения и общество дружбы «Узбекстан - Афганстан» посвщенным 100 летие независимосты Исламской Республики Афганистана 
изменений правила сфера влияний на территории других стран. Также свою роль сыграло началом острых стратегических противоречий между основными игроками. Именно с усилением глобализации крупные игрокам мировой политики характерным стал решение своих стратегических проблем непрямое непосредственно на территории других странах мира. Как печально Афганистан тоже оказался в этом процессе. В этом контексте за последний сорок лет Афганскому народу выпало трудное историческое испытание связанных с появлением и быстрыми темпами глобализации и вступлением международных отношений на новом этапе развития. На сегодняшний день эти вопросы требуют анализа под углом культурно гуманитарном измерении так как именно это фактор могут стать основным условием разрешением Афганского кризиса которым мирового сообщества безуспешно пытается уже несколько лет.

Во вторых, имидж государства на мировой арене ныне основывается не только на экономическом и военно-политическом но и культурно - гуманитарным и культурном потенциале. Новым фактором международного влияния стала «культурная дипломатия» государства. За счет интенсивных культурно гуманитарных связей с зарубежными странами, используя современной информационно коммуникационной технологии в сферы аудиовизуальной взаимодействие формируется привлекательный образ государства. В этой связи культурно - гуманитарная политика превращается в неотъемлемый компонент внешней политики современных государств. Сейчас стратегическая актуально приобретает культура как инструмент решения внешнеполитических задач и укрепления двухстороннего и сотрудничества.

В третьих, Во многих странах, в том числе и в Узбекистане, идут процессы формирования определенной модели культурно гуманитарного развития, влияющие на саму сущность духовных идеалов и нравственных принципов, которые сопровождается формированием культурноцивилизационного многообразия, развития открытых, информационно технологических и инновационных обществ, становления новой цивилизации образование. Вместе тем, наряду с этими усиливается процесс глобализацию экстремизма, терроризма Большинство стран сегодня сталкивается со схожими вызовами и угрозами, которые невозможно преодолеть в одиночку. Это и касается Афганистану. В таких условиях фактор науки, культуры, образования в укрепление и дальнейшего развития отношений между странами становится в высшей степени востребованной. Однако такие факторы используются в разрешении Афганского кризиса одним из последних.

В четвертых, новые вызовы начала века и масштабные задачи в области международных отношений в условиях глобализации придают культурно гуманитарным связям Узбекистана с Афганистаном все возрастающую значимость. Процессы глобализации влекут за собой не только взаимопроникновение и взаимообогащение культур, но и нередко ставят под угрозу культурную самобытность стран и народов. Перед лицом угрозы межцивилизационного разлома особое значение приобретают коллективные усилия по налаживанию культурно гуманитарного диалога. С другой стороне в мире многие страны стремится к гармонизации отношений, установление на культурно гуманитарного диалога, сотрудничество которые является одним из наиболее эффективных средств налаживания межцивилизационного диалога, достижения согласия и обеспечения взаимопонимания между народами, преодоления конфронтации в мире. В этой связи все острее встают проблемы сохранения и преумножения культурно гуманитарного наследия, а также более активного использования этих факторов на решение Афганского кризиса.

В пятых, Афганистан имеет свой истории и своя места в истории цивилизации человечества. Так как, Афганистан находясь культурно цивилизационным перекрестке между крупными регионами внесла свой вклад в развитии целого региона. Став связующий мостом между Азии и Европой способствовало распространение прогрессивных идей, опить, культуры. Все это способствовало значительное влияние оказало в формирование повестка дня взаимоотношений Узбекистана и Афганистана. Культурное ценности Афганского народа на сегодняшний день во первых, является одним из система образующим факторам, «ядрой» афганской государственности и использование этих факторов содействуют не только решение Афганских проблем но и развитие афганской государственности, экономики, социального развития. Во вторых, не только научным но и практическим вопросам стал использование этого ресурса в современном развитии Афганистана. Именно поэтому Узбекистан активно развивает культурногуманитарного диалога, регулярное проведение дней культуры стран, творческих мероприятий. В третьих, в свою очередь это спососбтвуют вместе государствами Центральной Азии формирование нового геокультурного и геоэкономического пространства связуюший между Востоком и Запада, между югом и севером.

Динамика сотрудничества в культурно гуманитарной сферы

Президент Узбекистана Шавкат Мирзиёев в своем выступлении на торжественной церемонии вступления в должность Президента Республики Узбекистан(2016 год) отметил, что тесное сотрудничество с зарубежными государствами, прежде всего с соседними странами, будет осуществляться на уровне современных требований, на основе принципов взаимного доверия и учета обоюдных интересов. Узбекистан неизменно остается приверженным открытой, доброжелательной и прагматичной политике в 
отношении своих ближайших соседей. Задачи региональной политики Узбекистана заключаются в обеспечении мира и стабильности, активизации взаимовыгодного и конструктивного политического, торгово-экономического и культурно-гуманитарного взаимодействия со всеми соседними странами.

Отдельное место в этих процессах занимает Афганистан, с которым Узбекистан связывают уходящие вглубь веков тесные узы дружбы и добрососедства, основанные на общности истории, культуры, традиций и ценностей. Следует отметить, что сегодня на территории Исламской Республики Афганистан (ИРА) проживает более 5 миллионов представителей узбекской национальности. Этнические узбеки принимают активное участие в созидательных процессах, происходящих в этом государстве, в т.ч. занимая высокие государственные должности.

Началу новой динамики в двусторонних отношениях послужила встреча Первого Президента нашей страны Ислама Каримова с главой ИРА Мухаммадом Ашрафом Гани в июне 2016 года в рамках Ташкентского саммита Шанхайской организации сотрудничества. Афганский лидер также провел встречу с Президентом Узбекистана Шавкатом Мирзиёевым 2 сентября 2016 года в Самарканде, на которой два лидера договорились приложить совместные усилия для придания принципиально нового качества сотрудничеству между странами.

М.А.Гани присутствуя на торжественном открытии портрета великого поэта и мыслителя, государственного деятеля, основоположника узбекской классической литературы Алишера Навои в Галерее выдающихся людей в президентской резиденции «Арг». выразил глубокое уважение к личности А.Навои и его бесценному наследию, связывающему узбекский и афганский народы. Президент Афганистана особо остановился на исторических узах между узбекским и афганским народами, схожести их менталитетов, общности культуры, языка, религии, обычаев и традиций.

Это подтверждает встреча Президента Исламской Республики Афганистан Мохаммада Ашрафа Гани 2017году с профессорско преподавательским составом и студентами Бухарского государственного университета. Мохаммаду Ашрафу Гани был вручен диплом о присвоении ему звания почетного доктора Бухарского государственного университета. «Я мечтал посетить Бухару, сыгравшую важную роль в развитии мировой науки и исламской цивилизации. Земля Узбекистана взрастила многих великих мыслителей, в числе которых Имам Бухари и Имам Термизи. Обучающаяся здесь молодежь воспитывается достойным предков личностями», сказал Президент Мохаммад Ашраф Гани.

По словам В.С.Бойко именно целостное, видение руководством Узбекистана развития ситуации в Афганистане привел к выработке совершенно новой, прагматичной и дальновидной политики в отношении Афганистана. В последние три года начал формироваться оптимистический взгляд на будущее мирного развития Афганистана. Плодотворно развивается сотрудничество в культурно -гуманитарной сфере. Свою роль начал играть Общества Дружбы «Узбекистан Афганистан», основной целью которого является дальнейшее развитие гуманитарных, духовнокультурных, научно-образовательных, просветительских отношений между народами Узбекистана и Афганистана. Наряду с этим в стране проведено ряд различного уровня научных форумов. Бесспорно, эти аспекты играют большую роль в дальнейшей развитии Афганистана.

В 2018 году в г. Термезе организовано по инициативе Узбекистана образовательного центра по обучению афганских граждан при Министерстве высшего и среднего специального образования. Данное образовательное учреждение имеет важное значение для подготовки с учетом потребностей афганской стороны квалифицированных специалистов со средне - специальным и высшим образованием для социально-экономической, транспортно-коммуникационной и других сфер. В настоящее время в центре секретами избранных ими профессий овладевают около 250 афганских юношей и девушек. Их обучают квалифицированные профессора и преподаватели высших учебных заведений нашей страны. В учебном центре также создана возможность для подключения к "Электронной образовательной системе" через корпоративную сеть высших учебных заведений и проведения дистанционных занятий с учеными и специалистами любого вуза Узбекистана. Информационно-ресурсный центр пополнен необходимой учебной литературой по технико-экономическим и социальногуманитарным направлениям, художественной и общественно-политической литературой, снятыми узбекскими режиссерами более 50 художественными и документальными фильмами, аудиодисками. В систему электронной библиотеки внесено более 700 электронных книг на латинице.

\section{Народная дипломатия}

В 2018 году создание общества дружбы «Узбекистан-Афганистан» стало историческим событием в отношениях двух государств. Хотя тесное торгово-экономическое, культурное сотрудничество между народами Афганистана и Узбекистана существует уже давно и имеет тысячелетнюю историю. Однако такая «народная» площадка, способствующая развитию взаимоотношений между Узбекистаном и Афганистаном на основе сближения историко культурных, материальных ценностей, представляющие народы двух стран создается впервые.

Это начал способствовать переходу к свободному от официально - формального, прямому человеческому общению началу, оказать содействие лучшему пониманию друг друга, развить фобии и стереотипы, способствовать формированию гармоничных отношений. Уже 
заметно вырисовываются прочные многоплановые связи в приграничных, торгово-экономических и культурных отношениях с соседними странами.

Известно, на территории Афганистана покоятся духи наших великих узбекских писателей и поетов , в их ряду Алишер Навои, Мирзо Бобур, Боборахим Машраб, Беруний, Лутфий , можно привести ряд других имен таких великих предков. Вклад этих великих ученых и творителей в развитие науки и литературы, является гордостью двух стран. И главной задачей узбекско афганского общества является более глубокое изучение в том числе совместное фундаментальное исследование наследие наших предков..

Обшество оказывает содействия сотрудничеству в культурно-гуманитарной и научно-образовательной сферах, которое также занимает важное место. Также направлена организации постоянное обмен мнениями в вопросах международных, научно - культурных вопросах между государственных и негосударственных организациями. В первую очередь, имеется виду доведение до общественности культурно - просветительского потенциала двух государств, посредством организации концертов, совместных выступлений писателей, художников, поэтов, архитектуры. Предусматривает организацию конкурсов клуба читателей, посещение работниками творческой деятельности исторических городов Узбекистана и в свою очередь организация визитов наших культурных деятелей в Афганистан; издание трудов молодых писателей, организация совместного издания журналов, особенно электронных изданий.

Важной задачей является привлечение гражданского сектора, объективная организация проведения совместных, международных проектов, направленных на повышение предпринимательской активности населения, особенно молодежи. Это также способствует укреплению отношений между государственными организациями, хозяйствующими

и предпринимательскими структурами, предусматривающих содействию и развитию предпринимательства в двух государствах, организация визитов Афганских предпринимателей в Узбекистан и узбекских бизнесменов в Афганистан.

Также оказывает содействии в укрепление и дальнейшее развитие в культурной сферы. Всем известно, что у двух народов большая тяга к ознакомлению с трудами, произведениями представителей искусства, культуры, театра, кино. Не будем скрывать, отсутствие в течение долгого времени обмена в этой сфере создало определенный пробел. Например, о существовании известных школ макомов в Афганистане и других видов искусства, или о работах мастеров, ремесленников мы знаем только через третьих источников. Между тем, на сегодняшний день, потребность в этом наблюдается не только у нас, но и в Афганистане. В связи с этим, общество будет организовывать совместные фестивали, ярмарки, выставки, в том числе фото выставки. Следует отметить, представители Афганистана активно участвуют в проводимых в Узбекистане различных международных научно-практических и культурных мероприятиях. В частности, В сентябре 2018г. делегация Афганистана приняла участие в Первом Международном фестивале макома в Шахрисабзе.

Совместно с правительственными и другими заинтересованными организациями содействие в укреплении гуманитарных, научно-технических, культурных связей, также партнерских отношений между городами и регионами Узбекистана и Афганистана. Например, делегация во главе с заместителем директора Академии наук ИРА М. Афзали приняла участие в международной научнопрактической конференции, посвященной великим историческим личностям и ученым (5-16 мая 2014 года, город Самарканд).12-15 марта 2016 года делегация Республики Узбекистан во главе с председателем Международного фонда имени Бабура 3. Машрабовым посетила город Герат, благоустроила территорию мавзолея Алишера Навои и отреставрировала мавзолей Камолиддина Бехзода.

Так же, организация визитов представителей парламента, ученых, специалистов нашей страны в Афганистан и их совместные выступления в послужат укреплению их взаимоотношений. Предусмотрено создание базы данных об Узбекистане и Афганистане, его достижениях в государственном строительстве, проводимых реформах. Это станет важным стимулом для понимания сущности и направленности проводимых реформ, модернизации различных сфер общества.

Организуются концертов, совместных выступлений писателей, художников, поэтов, архитектуры., конкурсов клуба читателей, посещение работниками творческой деятельности исторических городов Узбекистана и в свою очередь организация визитов наших культурных деятелей в Афганистан; издание трудов молодых писателей, организация совместного издания журналов, особенно электронных изданий. В сентябре 2018г. делегация узбекских ученых приняла участие в работе Международного симпозиума в Кабуле, посвященного жизни и деятельности Абу Райхана Беруни.14декабря 2018г. .в Ташкенте проведен Международный симпозиум, посвященный жизни и творчеству выдающейся представительницы Тимуридов Гавхаршодбегим.

Важной задачей является привлечение гражданского сектора, объективная организация проведения совместных, международных проектов, направленных на повышение предпринимательской активности населения, особенно молодежи. Это также способствует укреплению отношений между государственными организациями, хозяйствующими и предпринимательскими структурами, 
предусматривающих содействию и развитию предпринимательства в двух государствах, организация визитов Афганских предпринимателей в Узбекистан и узбекских бизнесменов в Афганистан.

\section{Конференционная}

дипломатия Узбекистана в отношений решение Афганского кризиса

Одним из серьезным причинам не решение Афганского кризиса является не использование научного культурно гуманитарного потенциала. С другой стороне умелое использование научные, научно практические конференции как культурно гуманитарный механизм консолидируют взгляда учёных, экспертов разных стран в решение Афганского кризиса. Именно поэтому в Узбекистане активно используются конференционная дипломатия как реальный инструмент в урегулирование региональных проблем и Афганского кризиса. За последные три года в Узбекистане проведено несколько международную конференцию направленных выработку модель решение Афганского кризиса. Где участвовали наряду с политиками учёные, специалисты и особое внимание была обращена на культурно гуманитарных факторов. Например, Ташкентская конференция по Афганистану (2018 г.) заложил начало в практическую деятельность действие мирового сообщество по разрешению афганскому кризису. Дальнейшие событий показывает что это было триуфом новейшей дипломатии Узбекистана.

Первое. Учитывая текущее состояние в Афганистане, сближение общих подходов и позиции стран Центральной Азии по афганскому урегулированию, вовлечение Афганистана в региональное сотрудничество, президентом Узбекистана Ш.Мирзиёевым было инициировано проведение в Ташкенте международной конференции по Афганистану «Мирный процесс, сотрудничество в сфере безопасности и региональное взаимодействие» (26-27 марта 2018г.). Проведении международной конференции высокого уровня по Афганистану в Ташкенте и дальнейшие действие показал логическим продолжением выверенного и конструктивного внешнеполитического курса Президента Узбекистана по выстраиванию добрососедских отношений со странами Центральной Азии и обеспечению мира, стабильности, безопасности и устойчивого развития в регионе и Афганистане. Ташкентская конференция по мирному процессу в Афганистане руководствуется двумя фундаментальными концепциями .Во-первых, это принцип неделимости безопасности. По словам Президента Узбекистана, это отказ от разделения угроз безопасности на «наши и чужие». Вовторых, региональная стабильность, в конечном счете, будет зависеть от успешной интеграции Афганистана в более широкую систему торговых, экономических и инфраструктурных связей с государствами.
Ташкентская конференция знаменует новую эпоху в региональном развитии и места Центральной Азии в международных отношениях. Президент Узбекистана отметил, что безопасность Афганистана это безопасность Узбекистана, залог стабильности и процветания всего обширного региона Центральной и Южной Азии. Нельзя допустить, чтобы международные террористические организации превращали Афганистан в своё постоянное пристанище.

Одним из решений вопроса афганского урегулирования, как подчеркивает руководитель страны, является проведение и организация переговоров между правительством Афганистана и движением «Талибан». Предложил создание всех необходимых условий - создании площадки на территории Узбекистана для организации переговоров, так как талибы, являясь частью афганского общества и гражданами Афганистана, имеют право голоса в определении будущего своей страны.

Руководством Узбекистана было отмечено, что республика поддерживает решение, принятое участниками второго заседания в рамках Кабульского процесса, которое ратовал за запуск прямых переговоров между афганским правительством и движением Талибан без предварительных условий и угроз применения насилия.

Таким образом, Узбекистан не только предоставляет площадку для переговоров, но и в дальнейшем будет стараться быть активным членом этого процесса. Ключевой особенностью инициативы и дальнейшие ее реализации является:

Во-первых, афганское урегулирование невозможно посредством использования «жесткой силы», не может быть решен военным путем. Узбекистан считает необходимым использовать региональную дипломатию, проведение переговоров и диалога между правительством Афганистан и противоборствующими силами, прежде всего с движением «Талибан», без предварительных условий.

Во-вторых, На конференции Президент Узбекистан также инициировал другое важное, не менее значимое предложение - создать специальный Международный фонд поддержки образования в Афганистане. Основная цель содействие афганской стороне в подготовке национальных кадров по самым востребованным специальностям, выделение стипендий и грантов для талантливых студентов и молодых учёных. Данное предложение Президента является логическим продолжением, инициированное Шавкатом Мирзиёевым в 2017 г. относительно создания Образовательного центра по обучению афганских граждан в Термезе (Узбекистан).

Ташкентская конференция по Афганистану не только способствует успешному вовлечению Афганистана в систему торгово-экономических и инфраструктурных связей региона, но и показывает мировому сообществу способность Узбекистана 
играть определенную роль в решении афганского вопроса путем многостороннего сотрудничества.

Итогом Ташкентского форума по Афганистану стало принятие Ташкентской декларации документа, отражающего политическую волю и взаимопонимание всех заинтересованных сторон по ключевым вопросам афганского урегулирования. Ташкентская декларация став важным документом, начал сыграть позитивную роль в процессе афганского урегулирования. Ташкентский форум предоставил возможность обсудить не только пути решения афганского кризиса, но и перспективы экономического развития региона, что в свою очередь, поспособствовал повышению уровня торговли и улучшению экономического благосостояния афганского народа. Ташкентская встреча подчеркнула потенциальное возрождение Узбекистана как дипломатического игрока в регионе.

Как результат этого форума в дальнейшем Узбекистан, по согласованию с официальным Кабулом, провел ряд важных переговоров с афганским руководством и представителями ведущих политических сил Афганистана, включая движение «Талибан». Все они признали, что Узбекистан может стать эффективным посредником в афганском урегулировании, так как поддерживает добрососедские отношения со всеми государствами региона, пользуется растущим доверием и авторитетом среди афганцев и в международном сообществе. Узбекистан создал все необходимые условия для организации на территории страны прямых переговоров между правительством Афганистана и движением «Талибан» ${ }^{2}$.

Второе. Состоявшийся в ходе прошедшей в Ташкенте в феврале 2019 года международной конференции: «Взаимозависимость в Центральной Азии: вызовы и новые возможности», подтвердил правильность курса Узбекистана на укрепление сотрудничества со странами региона и Афганистаном. Позиция Узбекистана касательно решения вопросов региональной безопасности и афганского конфликта через налаживание широкого многопланового сотрудничества между странами региона, включающего реализацию различных торгово-экономических, инвестиционных, транспортных и гуманитарных проектов, отражает новую геополитическую реальность в ЦА. Это показывает, что Центральная Азия и Афганистан не должны быть свободным столкновения геополитических интересов великих держав и региональных игроков. Регион должен стать пространством сотрудничества и взаимодействия.

Третьей. 21-22 июня 2018 году. в г. Ташкенте состоялась международная конференция, приуроченная к празднованию столетия Дня

$1^{2}$ См.: Спецпредставитель президента Узбекистана по Афганистану - о роли Ташкента, талибах и индийском независимости Афганистана. В ходе конференции основное внимание было уделено обсуждению перспектив развития узбекское - афганских отношений, взаимоотношениям Афганистана со странами Центральной Азии в культурной, политической и торгово-экономической сферах, а также выработке практических мер и предложений по развитию двусторонних отношений по приоритетным направлениям сотрудничества. Основные идеи сводились к следующим.

Во-первых, развитие мирного процесса. На сегодняшний день стратегия Узбекистана в диалоге с Кабулом сделала Ташкент значимым для всего международного сообщества переговорщиком по афганскому урегулированию. Такой подход не вызывает отторжения в самом Кабуле, поскольку он не подразумевает какого-либо вмешательства во внутри афганские дела. Практика последних десятилетий продемонстрировала, что попытки внешних интересантов решить внутри афганские проблемы неэффективны.

Узбекистан, со своей стороны, в полной мере сыграл свою особую роль в качестве соседа и «братской страны» Афганистана. Многократный процесс мирных переговоров является параллельным, и участие стран мира и региона становится все более очевидной. В 2018 г. мирный процесс в Афганистане заметно изменился, различные мирные переговоры прошли параллельно, мирная воля всех секторов Афганистана очевидна, международное сообщество уделяет больше внимания, и ожидается, что будут ощущаться перспективы мирных переговоров.

Афганское правительство активно продвигает процесс мирных переговоров под своим руководством. В феврале 2018 г. на втором раунде «Кабульского процесса» президент Афганистана А. Гани выразил готовность афганского правительства без предварительных условий вступить в мирные переговоры с талибами и осуществить ряд инициатив, включая прекращение огня и признание талибов законной политической партией в ответ на заявление талибов, призывающих к прямому диалогу с США, чтобы положить конец войне. Но призыв афганского правительства не был поддержан талибами, которые настаивают на отказе говорить с афганским правительством.

Во-вторых, вопросы экономического сотрудничества. Важность Афганистана как экономического партнера и рынка сбыта лучше всех осознали власти Узбекистана. Как отметил научный сотрудник Центра изучения Центральной Азии и Кавказа Института востоковедения РАН А.Воробьев, «на примере Узбекистана очевидно, что прагматичный и рациональный подход наращивания торгово-экономических контактов с Афганистаном укрепляет позиции инициативного

интересе // http://www.stanradar.com/bio/full/317mirziyoev-shavkat-miromonovich.html. 
партнера. В данном контексте эксперт считает, что важную роль в сотрудничестве стран Центральной Азии и России в афганском направление могут играть транспортно-логистические проекты. Один из таких перспективных проектов - проект строительства железной дороги «Мазари - Шариф Кабул - Пешавар». Представители России, Казахстана, Узбекистана, Афганистана и Пакистана - уже создали финансовый консорциум для реализации данного проекта, о своей готовности присоединиться к проекту также заявил Китай.

По мнению преподавателя Балхского государственного университета ИРА Ш.Шарифи, Афганистан всегда был и является неотъемлемой частью Центральной Азии, а мирный Афганистан способен обеспечить Центрально азиатским странам наикратчайший выход к портам Индийского океана и Персидского залива, соединить Южную Азию с рынками Европы и Китая. Качественным изменением во внешней политике стало изменение взгляда на эту страну не как на источник региональных проблем, угроз и вызовов, а как стратегическую возможность развить широкие транс региональные связи на всем евразийском пространстве.

В-третьи, вопросы безопасности. По мнению эксперта института марксизма университета Кайли КНР Ли Синьвэйа, сохраняющаяся нестабильная ситуация в области безопасности в Афганистане привела к большим жертвам среди гражданского населения. По данным Миссии ООН по содействию Афганистану (МООНСА), в период с февраля по май 2018 года произошло 5675 инцидентов безопасности, в которых инциденты вооруженного конфликта составили $64 \%$.

С 2018 г. антиправительственные силы, включая «Талибан», и террористические организации активизировали свою деятельность, и в Афганистане была совершена серия террористических нападений, растут также ориентации и убийства целей удара, что затруднило способность правительства Афганистана контролировать положение. В 2018 году число целевых убийств и террористических актовсамоубийств в Афганистане увеличилось соответственно на $35 \%$ и $78 \%$, по сравнению с аналогичным периодом 2017 г. Растет также уровень активности ИГИЛ в Афганистане, активно действующие в провинциях Нангархар, Кунар и Джаузджан.

По итогам мероприятий участниками подтверждена высокая востребованность в дальнейшем укреплении узбекско - афганского сотрудничества. Выработаны практические предложения по: совместно с афганскими исследователями и всеми заинтересованными учеными объединить интеллектуальный потенциал и усилия экспертов, аналитиков исследователей для разработки проблем общее единое пространство; центральной Азии и Афганистана; Сотрудничества в борьбе против терроризма, экстремизма и трансграничных преступлений; Водно энергетические, экологические аспекты развития Центральной Азии и Афганистана; Транспортные и энергетические коридоры в развитии Центральной Азии и Афганистана; Социально - экономические, общественно политические и культурно гуманитарные аспекты развития Центральной Азии и Афганистана. Созданием Международного института «Центральная Азия и Афганистан», который мог бы стать региональным аналитическим и экспертным центром, объединяющим исследователей всех стран региона и стать флагманом продвижения идей сотрудничества и новой атмосферы созидания в регионе.

\section{Заключение}

Таким образом изменения двухсторонних отношений Республики Узбекистан с Афганистаном последнего времени являются логическим результатом новой региональной политики Узбекистана которая рассматривает Центральную Азию в качестве одного из главных приоритетов внешней политики республики.

Наиболее перспективной, на наш взгляд, на этом направлении могла бы стать специальная программа Узбекистана совместно с Центрально Азиатскими государствами по формированию благоприятных условий для культурно гуманитарных связей с Исламской Республики Афганистан. В целях реализации комплексное меры в направлении подготовки специалистов и проведение фундаментальное исследовании создание «Международного Университета Афганистан.

Вместе с тем успешному решению афганского кризиса важнейшей предпосылкой является активное участие международного сообщества в деле восстановления Афганистана и укрепления институтов государственности, в обеспечении безопасности и стабильности в этой стране, важным составляющим должна стать непрерывная борьба с терроризмом и религиозным экстремизмом. И в этом процессе использование культурно гуманитарный фактор должен стать одним из составляющим системообразующим элементом. В связи с этим назрело время создания специальной площадкой $\mathrm{OOH}$ «Малый $\mathrm{OOH}$ для Центральной Азии и Афганистана». И назначение специального посла ООН в Афганистане по вопросам культурно гуманитарного развития также создание специального международного неправительственного института «Центральная Азия и Афганистан»

\section{Источники}

1.0 стратегии действий по дальнейшему развитию Республики Узбекистан Указ Президента Республики Узбекистан(Собрание законодательства Республики Узбекистан, 2017г., № $\quad 6, \quad$ ст. 70) 7 февраля 2017.,..,/ https://mfa.uz/ru/press/news/2017/07/11752/ 
2.Послание Президента Республики Узбекистан Шавкат Мирзиёева на Олий Мажлис (Народное слова.17 декабря 2017 год);

3. Послание Президента Республики Узбекистан Шавкат Мирзиёева на Олий Мажлис (Народное слова.124. декабря 2018 год);

4.Отчет о деятельности Министерства иностранных дел Республики Узбекистан за 2017 год

5.Отчет о деятельности Министерства иностранных дел Республики Узбекистан за 2018 год

6. Выступление Первого заместителя министра иностранных дел Республики Узбекистан Илхома Неъматова на брифинге в Центре «Стратегия развития»2018.12.25

7.Выступление министра иносранных дел Узбекистана А.Камилова на открытии международной конференции «Взаимосвязанность в Централной Азии: вызовы и новые возможности» (г.Ташкент, 19 февраля 2019г.)

8. https://mfa.uz/ru/(2017 2019тгг.)

9. http://jahonnews.uz/ru/politika

(2017_2019тгг.)

10.http://uza.uz/ru/business/nachala-rabotuprigranichnaya-torgovaya-zona-uzbekistan-afga-2305-2019(2017 2019тгг.)

11.http://cso.gov.af/en/page/economystatistics/6323/annual-trade

12. https://www.adb.org Asian Development Outlook (ADO) 2019: Strengthening Disaster Resilience.| April 2019

13.Э.Арипов. Узбекско-афганские отношения: новый этап динамичного развития. Xalqaro munosabatlar, 2018,1.

15.В.Норов .История конфликта в Афганистане и международные инициативы по его мирному урегулированию Xalqaro munosabatlar, 2018,1.17.

16. А.Умаров. Инициативы Республики Узбекистан в афганском направлении: потенциальные возможности и риски Xalqaro munosabatlar, 2018,1.

17.Ш.Абдуллаев.Исторические и культурноцивилизационные взаимосвязи народов Узбекистана и Афганистана Xalqaro munosabatlar, 2018,1 .

19. 20.Uzbekistan a year later: On the eve of a big strategic leap - article by Sayfiddin Juraev । regionaldialogue. Significant changes began in Uzbekistan in all...REGIONALDIALOGUE.ORG October 13, 2017
21. Жураев С,А Стратегический прорыв в политико - дипломатических отношениях Узбекистана государствами Центральной Азии.стр100-106.// «XX асрда жахон сиёсати ва узбекистон тажрибаси: сиёсий, хукукий, ва ижтимоий жихатлари:Узбекистон Республикаси Олий ва Урта махсус таълим вазирлиги микёсида илмий амалий конференция материаллари туплами» Т.ТошДШИ,2019;

22.Juraev.S.A. Afghan for Central Asia and Uzbek Prescription for its Treatment // The publication is brought out under the project Cooperative Development, Peace and Security in South and Central Development sponsored by Ministry of External Affairs (MEA), New Delhi, 2013, 2013. -pp. 65-70.

23.Афганистан на пороге XX и XXI веков: исторические, социально-экономические и политические аспекты, вопросы взаимного сотрудничества со странами Центральной Азии. // Материалы международной научно практической конференции.21-22 июня 2019года.Т.ТашГИВ, 2019.428 c

24.Спецпредставитель президента Узбекистана по Афганистану - о роли Ташкента, талибах и индийском интересе // http://www.stanradar.com/bio/full/317-mirziyoevshavkat-miromonovich.html.

25.Рашидов Р. Афғонистонда давлатчилик масаласи: тарих ва хозирги замон // Монография. Тошкент: «Наврўз» нашриёти, 2017 й. - 264 б.;

26.Туляганова Н.У. Афганский фактор в современных международных отношениях в Центральной Азии. Монография. - Т.: Фан, 2004. $211 \mathrm{c}$.

32..Умаров А.А.Фактор Афганистана в региональной безопасности Центральной Азии в начале XXI века. Автореф. дис. докт. философии (PhD) по полит. наук. - Т., 2017. - $48 \mathrm{c}$.

33.Выступление Президента Республики Узбекистан Шавката Мирзиёева на 72-ой сессии Генеральной Ассамблеи Организации Объединенных Нации. Официальный веб-сайт Президента Республики Узбекистан. 20.09.2017. https://president.uz/uz/lists/view/1063

34.Отчет для представителей СМИ по итогам переговоров Президента Республики Узбекистан Шавката Мирзиёева с Президентом Афганистана $\begin{array}{llll}\text { Ашрафом Гани. } & \text { УзА. } & \text { 5.12.2017. }\end{array}$ http://uza.uz/oz/politics/davlatimiz-ra-barining-afoniston-prezidenti-bilan-tkazilgan-05-12-2017 